\title{
Review: Challenges and Opportunities for Establishing a Security Community in the Wider Black Sea Area (2018)
}

\author{
Author: Mukhtar Hajizada \\ Journal: Southeast European and Black Sea Studies
}

DOI: $10.1080 / 14683857.2018 .1516333$

Since the demise of the Cold War period, the regional level has become increasingly recognised as the main level of analysis to explain international security conundrums but also the apposite conceptual locus to explore conflict and cooperation among states in the international system. Despite the abundance of regional organisations, however, many regions, like the wider Black Sea region - which encompasses the land and seascape from the Balkans to the Caucasus, and extends from the Russian and Ukrainian steppes to Anatolia in Turkey - seem to be anything but security communities, as attempts at regionalisation have left only an ersatz, nascent relation among states in search of the maturation of their interactions.

It is against this backdrop that Mukhtar Hajizada explores the possibilities and pitfalls of the non-emergence of mature relations among states in the wider Black Sea region. Employing the celebrated security community theoretical framework first coined by the eminent political scientist Karl Deutsch and then further developed by Adler and Barnett (1998) which divides security communities into nascent, ascendant, and mature as the three phases through which a security community emerges, Mukhtar forcefully contends that the security community in the region is still in its infancy as prospects for building such a community is well below par.

Any scholar well-versed in the complex regional dynamics of the wider Black Sea area would hardly disagree with Hajizada's contention. Indeed, the region which the author writes about is characterised by multifarious intrastate and interstate quandaries, dissent and lack of mutual trust: the longstanding political instability in Transnistria, separatist movements in Abkhazia and South Ossetia, and the ongoing Nagorno-Karabakh territorial conflict between Azerbaijan and Armenia, are amongst the many conflicts that still bedevil the region. Due to Russia's military capabilities and influence in the region, Hajizada contends that its actions are central to the pacification of the regional strife. The author, however, seems very pessimistic about the prospects of Russia intervening to quell the conflicts as it has almost always done the inverse: maintain its dominant role in the region by supplying weaponry to warring parties, intervening only when its own core national interests are at stake. 
But are these explanations by the author for the absence of a mature security community in the region sufficient? Regardless of the compelling arguments put forward by the author of this article, the fact that the article did not mention anything about democratic peace theory in relation to states in the region is rather unsatisfactory. The democratic peace theory posits that democratic states do not engage in armed conflict with one another. There are some explanations for this specific phenomenon: the institutional constraints - for example, the rule of law, public opinion, and representative government - militate against the utilisation of armed conflict by elite representatives in democracies and the concomitant normative preference for compromise.

Most, if not all polities in the Black Sea region are either hybrid regimes-sometimes termed "illiberal democracies" —or full-blown autocracies. Consider, by way of example, Freedom House's Nations in Transit 2018 which measures democratic transition in twenty-nine states in Europe and Central Asia. Without doubt, in this measure, none of the states in the region is a fully consolidated democracy: Russia and Azerbaijan are consolidated authoritarian regimes; Moldova, Ukraine and Georgia are aptly classified as hybrid or transitional regimes; Armenia is a semiconsolidated authoritarian regime; Romania is a semi-consolidated democracy as are most other Eastern European countries. Does this dearth of democratisation explicate the resort to armed conflict by these states in the resolution of their conflicts, and thus the preclusion of the formation of a mature pluralistic security community? One can equally contend that the regime type of these countries cannot be discounted with regards to their foreign policy choices and the continuation of the internal strife and interstate conflicts that are ongoing in this important region. Hajizada's article unfortunately fails to pinpoint this crucial factor which increasingly contributes to undermining the emergence of a mature security community. Perhaps a drive toward democratisation would be necessary and sufficient to build the much-needed security community.

Notwithstanding the limitations highlighted herein, this article is well-researched, sound, and lucidly written; even non-experts on the region will find it persuasive.

\section{References}


Reviews: Articles

Adler, Emanuel and Barnett, Michael (eds), Security communities (Cambridge: Cambridge University Press, 1998).

\section{PROMISE FRANK EJIOFOR}

Central European University

This work is licensed under the Creative Commons Attribution 3.0 Unported License. To view a copy of this license, visit http://creativecommons.org/licenses/by/3.0/ or send a letter to Creative Commons, PO Box 1866, Mountain View, CA 94042, USA. 